\title{
Hamlet, Art, and Apoptosis: The Shakespearean Artwork of Julie Newdoll
}

\author{
MARCIA EPPICH-HARRIS
}

\begin{abstract}
Contemporary artist Julie Newdoll's painted series "Shakespeare: The Mirror up to Science" explores the connection between Shakespeare's Hamlet, suicide, and science. Using the thesis supported by the work of Burton R. Pollin that Hamlet's revenge is fueled by his desire to commit suicide, Newdoll shows how the biological process of apoptosis-that is, programmed cell death-can be used as a metaphor for Hamlet's suicide narrative through her paintings.
\end{abstract}

KEYWORDS: Hamlet, suicide, science, art, Shakespeare

Works like Hamlet, which have been shown over centuries to have enough coherence and mystery to touch off major transformations in Western culture, are both challenges and standing invitations.

-KERRIGAN, XII

Just over thirty-five minutes into the RSC's 2009 film version of Hamlet, the melancholy prince (David Tennant) looks into the camera with wildeyed determination and swears to remember his murdered father. Hamlet pulls out a switch blade and flicks it open, saying, "Now to my word: / It is 'Adieu, adieu! Remember me." Hamlet stares at his left hand before finishing the speech with "I have sworn it," then grasps the blade in his fist and deliberately slides the knife through his palm, mutilating and handicapping himself as he begins the journey to avenge his father's murder. The effect is startling, both to the viewer and to Hamlet himself. He crumples to the

INTERDISCIPLINARY LITERARY STUDIES, Vol. 17, No. 4, 2015

Copyright @ 2015 The Pennsylvania State University, University Park, PA 
floor in pain and horror. In watching this interpretation, one gets the feeling that if Hamlet is determined to follow through with his vengeance, then this early self-inflicted wound is only the first of many potential bloodlettings he will endure. A cut only inches below the palm would have been deemed a suicide attempt. Instead, mad-eyed and manic, Hamlet uses this cutting gesture as a blood oath to avenge his father. But just as he completes the pledge, his fall to the floor illustrates how overwhelmed he is. Yet, despite his surge of emotion, Hamlet must instantly revive in order to deal with Marcello and Horatio. David Tennant's Hamlet reacts to every outside stimuli impulsively, with a kind of death-wish intensity that is at once unpredictable and frantic. This particular interpretation of the character shows Hamlet to be always on the verge of suicide, whether there is a knife in his hand or not.

Tennant's Hamlet supports a reading for which Burton R. Pollin, among others, has argued-that Hamlet's suicidal tendencies drive him to complete his revenge quest. The implication is that Hamlet plans to kill Claudius in order to ensure his own death as a result. In other words, the revenge tragedy is also a suicide narrative. Coupling Hamlet's suicidal tendencies with his meta-awareness that revenge heroes almost always die $^{1}$ as a result of seeking revenge, one may argue that Hamlet's acceptance of his revenge quest is also an acceptance of his own imminent demise, which Hamlet describes in the "To be" speech as "a consummation / Devoutly to be wish'd" (3.1.62-63). Although Hamlet does not die by his own hands directly, his death may still be considered a suicide because it occurs as a result of what Jean Baechler calls "indirect suicide"; that is, any and "all behavior that is bound to provoke a homicidal reaction in another. That is, provocation pure and simple." ${ }^{2}$ Baechler's view also supports the claim that revenge quests will result in reciprocal violence, which for the self-aware individual would be considered indirect suicide, or in current nomenclature, a kind of suicide-by-cop.

The best person to seek vengeance is one who is ready to die because the consequence of revenge is most often the death of the revenger. Girolamo Cardano's Cardanus Comforte, translated into English in 1573 by Thomas Bedingfield, and famously considered to be the book Hamlet reads when Polonius happens upon him, discusses the danger of seeking revenge because of the dire consequences: "For what can be more foolish than to seek revenge, when safely it cannot be performed." ${ }^{3}$ If, indeed, Hamlet were reading Cardanus Comforte in the fictional world of his play, he would be aware of the consequences of his actions, if his Wittenberg education had 
not already alerted him that the "Everlasting" has "fix'd / His canon 'gainst self-slaughter" (1.2.131-32). ${ }^{4}$ Hamlet understands the consequences of his actions if he pursues the murder of the king, even if that murder is justified. When Hamlet learns of his father's murder and call to revenge, he says,

O all you host of heaven! O earth! what else?

And shall I couple hell? O, fie! Hold, hold, my heart;

And you, my sinews, grow not instant old,

But bear me stiffly up. (1.5.92-95; emphasis added)

By contemplating a "coupling" with hell, we see intimations of Hamlet's understanding of the consequences of seeking vengeance. He will put his soul in peril by murdering his uncle. In committing to the revenge quest regardless of the consequences, including his certain death as a result, Hamlet commits himself to both a revenge narrative and to a suicide narrative.

While film or stage productions are the most obvious ways Shakespeare's works are interpreted outside of the literary medium, they are not limited to dramatic, or even textual, interpretation. Characters and scenes from Shakespeare have also been the preoccupation of artists for centuries. Artists such as Dante Gabriel Rossetti, John William Waterhouse, and Eugene Delacroix used Shakespeare as a way to express the individualism and pathos of the Romantic period. They have also given us insight to the characters and the plays themselves, sometimes interpolating imagery in order to support a particular reading, just like Tennant's suicidal knife-wielding Hamlet does. Contemporary artist, Julie Newdoll, follows this tradition of using literary subject matter in art, but adds a twist to the standard literary painting in that she uses literature and mythology in her artwork as a way to illustrate the sciences metaphorically.

Newdoll is a professional artist who also has a degree in microbiology and a master's in medical illustration. For over twenty years, Newdoll's work has been featured on the covers of scientific journals and magazines such as Cell, Nature Reviews Genetics, Nature Reviews, Molecular Cell Biology, Structure, PLOS, American Scientist, and others. Newdoll's work "merges life science and culture, myths and molecules," frequently using scenes or characters from literature, such as the Romantics mentioned above, as components in her paintings. ${ }^{5}$ In 2009, Newdoll started painting a series on Shakespeare's Hamlet. Completed in 2012, the series, Shakespeare: The Mirror Up to Science, illustrates Pollin's reading of Hamlet 
that understands the play not only as a revenge tragedy but also as a suicide narrative. ${ }^{6}$

The link between Newdoll's science-inspired art, Hamlet's revenge quest, and the concept of suicide comes in the form of the biological process of apoptosis. Apoptosis is defined as programmed cell death-or cellular suicide-and is part of the natural development of all multicellular organisms, animals and humans alike. According to Bruce Alberts, et al., humans experience cell death in a variety of ways-in the womb through the creation of individual, instead of webbed, fingers; in the formation of vertebrae; and so on. The cells are described as "committing suicide" for the good of the body and the advancement of normal development. ${ }^{8}$ If cells did not die, there would be lasting implications for the larger organism. For instance, in a study that examined mutations in ringworms, Hillary Ellis and Robert Horvitz learned that mutated cell survival often led to abnormality and/or the death of the organism. ${ }^{9}$ In order to preserve the body's normal development and functioning, some cells must die for the greater good.

Newdoll's work suggests that Hamlet's indirect suicide acts as a restoration of order in the body politic, just as apoptosis saves the body from abnormality and disease. While Hamlet's suicide narrative might not appear to be motivated by a desire to restore order in the rotten state of Denmark, it seems that a scourging must occur in order for Denmark to survive as an independent "body." The problem in Denmark is not so much that there is tension within the state-although that is true-instead, the essential problem is that few, if any, people at court acknowledge that anything is wrong with the recent events that vex Hamlet so deeply. The death of King Hamlet and the subsequent marriage of Gertrude and Claudius are accepted as a matter of course to everyone in the play, except Hamlet, notwithstanding Marcellus's famous assertion. Horatio is sympathetic to Hamlet, but not openly critical of the heads of state. Claudius and Polonius ridiculously conspire to find a different cause for Hamlet's "distemper" other than what Gertrude asserts is "the main, / His father's death and our o'erhasty marriage" (2.2.55-57). Before Hamlet knows the truth, he laments that he cannot kill himself because of religious reasons in act 1 . But when the call to revenge his father's murder comes, Hamlet is the perfect candidatenot because he is his father's son and has a filial obligation, but because Hamlet already wants to die.

Hamlet's zeal for revenge in the Ghost scene fades into the delays and stratagems of acts 2 and 3. Had Hamlet's commitment to revenge been strong enough from the outset, the play would have been over before 
act 2 began. These tactics, however, mirror apoptosis. Alberts, et al., describe the five-step process of cellular suicide: (1) A message is sent to a cell; (2) proteins both inside the cell and outside the cell perform tests to see if destruction is necessary; (3) the cell commits either to suicide or to survival based on the results of the test, making the process irreversible; (4) cellular breakdown; and finally (5) the cell becomes surrounded by a phagocytic cell, is packaged, and neatly eliminated. ${ }^{10}$ Through this process, order is restored within the body and normal development and functioning can continue. The scenes Newdoll selects for her paintings demonstrate that the suicidal drive described in apoptosis is at the core of Hamlet.

In the first stage of apoptosis, a message, or signal, is sent to the cell. This stage is portrayed in Newdoll's The Arrival of the Death Message (Fig. 1). Here, we see Marcello and Horatio swearing upon Hamlet's sword not to reveal what they know about the Ghost. Newdoll's use of this scene signifies that Hamlet has received the "death message" and that the processes of revenge, and thus the hero's death, have begun. The painting shows a wintery scene at Kronberg Castle, located in Helsinore, Denmark. ${ }^{11}$ The Ghost is visually reflected on the sword that the men gather around, as he commands them to swear upon Hamlet's sword. Newdoll chose to represent the death message in apoptosis through the three men because:

a message comes to the cell as a protein composed of three identical parts bound together in what would be called a "trimer" in biology. ... The sword is a perfect metaphor for the science as well, since the next phase in the apoptotic process involves puncturing the internal energy-making organelle of the cell. ${ }^{12}$

An oval "cell membrane" frames the scene, creating a kind of mise en abyme-the Hamlet metaphor contained within the cellular metaphor. Expanding the mise en abyme are the objects within the frame: weapons used at the end of the play-poisoned swords centered at the top, the poisoned cup to the right, a dram of poison to the left which has the alchemical symbol for arsenic on it. Linking the murders at the end of the play to this early moment shows the implications of the scene. Even the women in the play are represented, as four groups of three women are reaching into the primary picture from each grouping of three skulls on the outside of the membrane. Newdoll states that "the four groups of woman may be thought of as the protein trimer that spans the membrane which receives the death signal and transmits it into the cell; the women in the play; the keres, from 
Greek mythology; and Hecate, triple goddess." ${ }^{13}$ At the bottom of the frame, we see skulls and warriors riding horses. The warriors indicate the usurpation of the throne-first by Claudius, and again at the end of the play, by Fortinbras.

The colors in this painting show a vibrancy that adds detail and luster to the moment. The swirling clouds in the background support the theme of great unrest in the kingdom. The men's hair, as well as a Danish flag in the background, show that the wind is blowing the clouds away to reveal a beautiful starry sky, featuring at the center Tycho's Supernova, discovered by Tycho Brahe in $1572 .{ }^{14}$ Symbolically, the clearing of the air to restore the kingdom's order and beauty contrasts with the mortal imagery surrounding the primary picture. While there is movement, openness, and a sense of a grand landscape within the blue-hued center of the painting, the outer frame in oranges, reds, and yellows adds the feeling of claustrophobia, as if the frame could collapse on the men at any moment. The tension produced by the contrasting colors gives us a sense of urgency about the implications of the Ghost's cry for revenge. With all these elements in mind, The Arrival of Death Message shows the catalyst to Hamlet's mission and creates the first link to apoptosis.

In the second painting, The Mousetrap: Checkpoint on the Path to Destruction (Fig. 2), Newdoll presents the play within the play in that Hamlet uses to "catch the conscience of the king" (2.2.540). This famous mise en abyme is set in the great hall of Kronberg with a temporary stage placed before a mirror flanked by tapestries. The tapestry on the left is based on an actual tapestry at Kronberg. It shows two men-one a king, the other a knight. Beneath them, biological imagery shows "the external stimulus that causes Hamlet to do the deed [seek revenge]." ${ }_{15}$ The tapestry on the right shows Hecate; beneath her we see the internal stimulus of apoptosis. ${ }^{16}$ The apoptotic process is linked here to the Mousetrap because a series of "tests" must be done in the process of apoptosis in order to verify that cellular destruction must take place. Just as Hamlet is testing Claudius's guilt with the play to verify that revenge is necessary, a cell will test itself to see if death is the appropriate course of action. ${ }^{17}$

In the foreground, we see (from left to right) Polonius, Ophelia, Hamlet, Claudius, and Gertrude. In the mirror's reflection, we can see Horatio on the far right watching Claudius. The reflection also shows the royal couple's reactions: Gertrude's puzzled expression and Claudius's crumpling face. We also see the hooded figure of the Ghost reflected in the mirror, watching the proceedings and symbolizing the catalyst for this test. In the foreground, 
Hamlet scrutinizes Claudius. Claudius's features are sullied with guilt and rage as he prepares to rise.

In the middle ground, the play-or the test-goes on. Two figuresthe Player King and murderer, Lucianus - are at center, staging a symbolic regicide. Lucianus's gaze rests on Hamlet, not his victim. But Hamlet, turned to Claudius, is in the process of describing the action, saying, "[The murderer] poisons him i' th' garden for his estate. His name's Gonzago. The story is extant and written in very choice Italian. You shall see anon how the murderer gets the love of Gonzago's wife" (3.2.254-57). Both the king and queen react to Hamlet's explanation-the king with rage, the queen with confusion. From the viewer's perspective, Ophelia and Polonius's reactions are hidden. However, Ophelia's head inclines toward Hamlet in an intimate gesture. Her closeness to Hamlet appears to resist both Polonius's orders to reject Hamlet and Hamlet's own rebuffs in act 3, scene 1. Ophelia's positioning shows her instability and that she is literally caught between Polonius and Hamlet, torn between her loyalty to her father and her loyalty to her lover. In this scene, she plays the role Hamlet assigns to her-a puppet he toys with-and the way she leans into him shows her willingness.

The decorations of the backs of the chairs also illustrate cell death. The designs on the backs of Hamlet and Claudius's chairs are simplified illustrations of the RNA/DNA material unraveling during the process of apoptosis. Polonius's chair shows greater decay than Hamlet's, signifying that Polonius's death is imminent. Gertrude's chair design echoes the wall hanging beneath Hecate with the oblong cell going through the testing stage of apoptosis. The oblong cell beneath Hecate vaguely seems to spell out the word "man," which to Hamlet, of course, is the "quintessence of dust" (2.2.302).

The third painting in the series, The Commitment (Fig. 3), portrays Claudius praying after the play within the play. Though chronologically this painting comes after the ghost scene and the mousetrap, it was the first painting that Newdoll completed. Beginning the series in medias res, Newdoll shows that Hamlet's commitment to revenge is the most important aspect of the series because that commitment to murder is also a commitment to Hamlet's own inevitable destruction as a consequence. This commitment most strongly affiliates Hamlet with apoptosis in Newdoll's view. In the painting, Claudius kneels in the foreground, his face gazing in profile upward and out to the heavens. We see in the window the silhouette of a crown, perhaps the chief object of his gaze, and a strange halo of a moon, which resembles a cell and its nucleus. Behind Claudius, Hamlet stands in 
the middle ground, framed in a doorway, sword drawn. It is at this moment in act 3, scene 3, that Hamlet could have consummated his revenge:

Now might I do it. But now 'a is a-praying.

And now I'll do it [Draws sword] — and so 'a goes to heaven, And so I am revenged! (3.3.73-75)

Hamlet's hesitation at this moment, of course, comes when he registers that killing Claudius during the purgation of his soul would undermine the potential for-in Hamlet's mind-true revenge: that which extends beyond mortal life.

Before this moment in the play, Hamlet is not fully committed to the revenge plot because of his own doubts-both about the Ghost's veracity and his own willingness to condemn himself, as demonstrated at the end of act 2:

The spirit I have seen

May be a dev'l, and the dev'l hath power

T' assume a pleasing shape, yea, and perhaps,

Out of my weakness and my melancholy,

As he is very potent with such spirits,

Abuses me to damn me. (2.2.578-83)

But now, in act 3, scene 3, having witnessed Claudius's reaction to the play and with his resolve firmly in place, we see Hamlet committing to true revenge - a revenge that will ensure Claudius's damnation:

Up, sword, and know thou a more horrid hent:

When he is drunk asleep, or in his rage,

Or in th' incestuous pleasure of his bed,

At game a-swearing, or about some act

That has no relish of salvation in't-

Then trip him, that his heels may kick at heaven,

And that his soul may be as damn'd and black

As hell, whereto it goes. (3.3.88-95)

While Hamlet does not contemplate his own fate at this moment, it was clearly on his mind prior to the play within the play, during the "To be" speech. The fact that Hamlet has no lines between the end of act 2, when he 
decides to set up the Mouse Trap, and the "To be" soliloquy suggest that in his off-stage moments, Hamlet has been contemplating the consequences of action. I would argue that Hamlet's contemplation of suicide comes in reaction to the idea that very soon he will have his answer regarding Claudius's true guilt. Contemplating death follows naturally for this revenge hero when the possibility for revenge is in sight. Despite the anxiety Hamlet feels about the afterlife and his admission that he is stymied by conscience, this contemplation of death is necessary for Hamlet to fully commit to revenge. His acceptance of and resignation toward what he calls cowardice and inability eventually resolves in act 5, when he realizes that "There is special providence in the fall of a sparrow" (5.2.202-3) ${ }^{18}$ Although Hamlet is burdened with the revenge quest, here in act 5 , he is resigned: "If it be now, 'tis not to come; if it be not to come, it will be now; if it be not now, yet it will come-the readiness is all" (5.2.203-5). Not only is Hamlet ready to consummate his revenge, he is also ready to die: "Since no man, of aught he leaves, knows what is't to leave betimes, let be" (5.2.205-6). Thus, Hamlet, one may say, commits to suicide when he commits to revenge. The problem is that Hamlet's commitment to vengeance, like a tornado, destroys everything in its path. Hamlet becomes the scourge of Denmark, as he admits to Gertrude after accidentally killing Polonius:

For this same lord,

I do repent; but heaven hath pleased it so

To punish me with this, and this with me,

That I must be their scourge and minister. (3.4.156-59)

As a scourge, Hamlet destroys not only the usurper king, but also all of the complicit actors around him, including Polonius and his family, and Gertrude. But also, as noted by Wofford's edition of Hamlet, "Scourge suggests a permissive cruelty (Tamburlaine was the 'scourge of God'), but 'woe to him by whom the offense cometh'; the scourge must suffer for the evil it performs." ${ }^{19}$ Hamlet, as a scourge, is all the more fated to die and he knows it.

In the painting, The Commitment, we look at the scene through an ornate doorway with twisting emerald columns. The columns resemble the double helix design of DNA. The bottom of the columns are breaking apart, representing cellular destruction, as well as the corruption that threatens to destroy Denmark. Above the outer doorway, we see the naked figures of Hamlet on the left and Ophelia on the right. Their nakedness suggests a sexual relationship between the pair, and Ophelia's belly protrudes slightly 
to indicate pregnancy. These figures represent an alternate reality for the couple-what might have been had Hamlet not been called to revenge his father. Flowers support Ophelia's legs, reminding us of the significance of flowers in her mad scenes and in the description of her death. Beneath each character, scrollwork separates Hamlet and Ophelia from cells that are popping and disintegrating-apoptosis in action-which foreshadows the destruction that will take place after the cell has committed to suicide. Additionally, these cells could also signify the death of Hamlet and Ophelia's relationship, which we see in act 3 , scene 1 , prior to the moment portrayed here and in the previous painting.

Situated between Hamlet and Ophelia is Hecate, here portrayed as the goddess of the crossroads, as two paths diverge behind her. Hecate's presence signifies multiple meanings. First, that Hamlet and Ophelia's relationship has passed into a dimension that can no longer include the possibility of love, marriage, and progeny. But additionally, Hecate's presence shows that the moment framed within the doorway is a crossroads for Hamlet in the revenge narrative.

The question of political order in Denmark is also represented in the golden crown above the doorway, placed just above the image of Hecate. Crowns appear several times in the painting-above the doorway, on Claudius's head, in the distance outside the window, on Hecate's heads, and on the heads of figures (a king and queen) that flank the fireplace. While crowns indicate the power struggle inherent in the play, the checkered floor $^{20}$ in the room indicates high-stakes game play with the suggestion of chess pieces surrounding the fireplace-the queen and king on either side of the mantle, bishop-shaped andirons on the floor, and rook-like columns that frame the fireplace. Additionally, seen within the fireplace is the ghost of Hamlet's father, walking among the flames. While the Ghost is not present in the play script at this moment, his order to seek revenge weighs heavily on the scene and impacts the political strategies that Hamlet considers. Although he is the rightful king, the Ghost does not wear a crown, but is shown here and in the other paintings in a hooded robe, calling to mind images of the Grim Reaper, the personification of death.

The crown is not the only political image within the painting, however. Above the doorway where Hamlet stands is another mise en abyme-a painting within the painting showing a warrior in a ship. This painting indicates the Norwegian prince, Fortinbras, who by default inherits the kingdom at the end of the play. Additionally, looking behind Hamlet's doorway, we see that he is leaving a room that is bright with light and 
is entering into darkness. The light behind Hamlet indicates his loss of innocence regarding his parents' relationship, which he describes in act 1 as being idyllic, as well as Hamlet's entry into the sinister world of revenge and murder. Hamlet stands at the threshold of darkness, indicated by the shadowy quality of the chamber where Claudius prays. Silhouetted in the doorway, Hamlet has become completely dark at this point, instead of simply wearing the black clothes of mourning. Representing the darker qualities of his inner self, Hamlet's shadow stretches before him and merges with the royal purple robe of Claudius. The combination, significantly coming together over the chessboard flooring, indicates that Claudius's corrupt and murderous politics has brought out the vengeful and suicidal qualities in Hamlet, and also, that the royal robes are debased with the shadow of usurpation that hangs over them.

The fourth painting of the series, Apoptosis Phase 4; Apoptotic Bodies at Ophelia's Funeral (Fig. 4), represents the fourth stage of apoptosis: cellular destruction. Newdoll links this stage of apoptosis to Hamlet by giving us a worm's eye view of Ophelia's grave. The soil surrounding the hole shows cells that are disintegrating and are in various stages of death. Similarly, the featured characters in the scene are also in various stages of death-Laertes perhaps is the strongest character indicated in the scene, despite initially throwing himself into the grave to be buried with his sister. In the painting, Laertes tries to strangle Hamlet, foreshadowing his upcoming association with Claudius and their conspiracy against Hamlet. Hamlet, while not meeting his death in this scene, is already resolved to die, and in fact, dares the assembly to bury him alive, along with Ophelia and Laertes (5.1.265). Finally, Ophelia serves as a contrast to the men, as her corpse lies to the left as the men grapple with each other. Each figure in the stages of eventual or actual death mirrors the apoptosis happening around them. Above the three figures, hands of the funeral attendees reach for the men in a chaotic attempt to stop the fighting. To the left, the white gloved and glowing hand of the queen reaches for the men in a feeble attempt to put off the inevitable destruction of Hamlet. The darker-hued hand of Claudius stays Gertrude's hand. The only hand that is not reaching for Laertes and Hamlet in the painting is Claudius's, indicating Claudius's desire to eliminate Hamlet.

Newdoll's depiction of Ophelia contrasts the Romantic visions of her from the nineteenth century, rejecting the total-victim mentality often associated with her suicide. Instead, Newdoll emphasizes the ambiguity of her role in the play. In the painting she appears to be doll-like in death, 
indicating the puppetry with which Polonius, Claudius, and even Hamlet used her, and she is dressed as if in a wedding gown. The virginal stark whiteness of the gown creates tension between the binaries of Ophelia as an innocent victim and Ophelia as a wide-eyed accomplice to the plot to bring down Hamlet. Ophelia's madness is explained in the play as a result of her father's murder by Hamlet. However, when the Gentleman describes her mad state in act 4, scene 5, we can see that there is potential for even darker ruminations: "She speaks much of her father; says she hears / There's tricks i' the world; and hems, and beats her heart" (4.5.4-5; emphasis added). Ophelia seems to understand-more clearly, ironically, in her madnessthat corruption has infiltrated every aspect of her life, including both her relationships with her father and Hamlet, and the political realm in which she lives. Ophelia's ramblings confuse their audience, moving "the hearers to collection" (4.5.9) and forcing them to interpret her melancholy, much in the same way that the court tried to interpret Hamlet's depression in acts 1 and 2. When Gertrude hears the report, her response, in an aside, could apply not only to her own guilt, but also to Ophelia's: "So full of artless jealousy is guilt, / It spills itself in fearing to be spilt" (4.5.19-20). Applied to Ophelia, this proverbial phrase could indicate that Ophelia's madness and subsequent suicide may in fact be due to her guilt associated with betraying Hamlet in favor of her father's will.

Back in the grave, Ophelia's involvement in Hamlet's manipulation by Polonius and Claudius is reified by the intertwining of her legs with Hamlet's as he struggles against the sole remaining male of Polonius's family. A funeral wreath falls into the grave, raining petals upon the scene, reminiscent of act 4, scene 5, when Ophelia distributes flowers among the members of the court. The skull beside her foregrounded leg, another indication of death and destruction, may well be Yorick's skull. Yorick, whom Hamlet remembers with fondness as "a fellow of infinite jest" (5.1.171-72), has become yet another piece in the illustration of death and the long road toward destruction. Hamlet says to the skull in act 5, "Not one now to mock your own grinning-quite chop-fall'n. Now get you to my lady's chamber, and tell her, let her paint an inch thick, to his favor she must come; make her laugh at that" (5.1.179-82). Ophelia's face, literally and figuratively painted white, is trapped in a death gaze that has as much ability to laugh as Yorick's skull to attempt its inspiration. The actively dying cells around the grave allow for no mirth here, as well, and as the soil froths in destruction around the characters, it is only a matter of time before Hamlet finds himself encased in his own princely tomb. 
The tomb is exactly where Newdoll ends her painting series. The fifth painting, After the Dead March (Fig. 5), indicates the final stage of apoptosis, in which the dead cell is packaged and eliminated. The play ends with Fortinbras's order to bear Hamlet away, so Newdoll shows an imagined entombment for the prince and his parents. The scene of the painting is based on the interment room of Christian $\mathrm{IV}^{21}$ of Denmark in Roskilde Cathedral. ${ }^{22}$ Christian's portrait is shown in this painting in the upper right hand side of the border around the main painting in the room. Opposite Christian is the astronomer, Tycho Brahe (1546-1601), who Newdoll refers to both here and in the first painting of her series, because of Brahe's potential influence on Shakespeare's composition of Hamlet. ${ }^{23}$

We see three coffins in the foreground. Each coffin has scientific imagery on it that links the coffins to apoptosis. From left to right, the coffins appear to encase King Hamlet, Prince Hamlet, and Queen Gertrude. Each coffin has an inscription. King Hamlet's coffin says "Eternal." Newdoll's brushwork highlights "RNA" found within Eternal. Shakespeare uses the word "eternal" twice in Hamlet. The first time, the Ghost of Hamlet's father uses it when he truncates the description of the woes of his afterlife: "But this eternal blazon must not be / To ears of flesh and blood" (1.5.21-22; emphasis added). The second time "eternal" is used is when Fortinbras enters the deadly scene of act 5 , scene 2 :

This quarry cries on havoc. O proud death, What feast is toward in thine eternal cell, That thou so many princes at a shot

So bloodily hast struck? (5.2.346-49; emphasis added)

The death scene witnessed by Fortinbras has been tidily packaged and removed in the painting, signifying the final process of apoptosis. However, at the center of the stage, we see a painting within the painting, indicating the events that lead to this interment. Within that painting, Hamlet pours the poisoned liquor down Claudius's gullet, as Gertrude lays nearby, having fallen backward over her throne to die. The king's crown has fallen carelessly aside. The entire court of Denmark stands by, watching as the king and queen die. Barely noticeable, unless seeing the painting in person, is the Ghost standing within the crowd, the ninth figure from the right, placed between two figures, one in yellow (left) and the other in blue (right). The dead body of Laertes lays prostrate on the floor in front of him. Behind the crowd, three more paintings hang on the walls of the painting within the painting. The center 
painting, though abstract, suggests a reproduction of Romantic portrayals of Ophelia-a young girl in the water, unaware of her doom.

Hamlet's coffin inscription says, "Let all the battlements their ordnance fire"- "DNA" from "ordnance" is highlighted. This quote is from Claudius's lines before the fencing match between Hamlet and Laertes:

If Hamlet give the first or second hit, Or quit in answer of the third exchange,

Let all the battlements their ordnance fire. (5.2.250-52; emphasis added)

Although the quote is spoken by Claudius, the coffin is indicated as Hamlet's by three details-first, the skull on the top of the coffin has no crown on it, but sits atop an open book, indicating the person inside had not been a king, but a scholar; second, the coffin is black-the color most often associated with Prince Hamlet. Finally, when Fortinbras orders that Hamlet's body be buried, he adds that the people should "bear him like a soldier" (5.2.378), and at the top of the face of the coffin are two cannons and two crossed battle flags.

On the final coffin, Gertrude's, we see the phrase, "To thine own peace." According to Newdoll, "peace" is a pun for the pieces of the cell that fall apart and must be packaged in order to be eliminated from the body (Newdoll, "Painting Series on Hamlet"). Claudius also is the source of this quote. When he and Laertes are conspiring against Hamlet, Claudius says in response to Laertes's worry that Claudius will force Laertes into peace with Hamlet,

To thine own peace. If he be now return'd,

As checking at his voyage, and that he means

No more to undertake it, I will work him

To an exploit, now ripe in my device,

Under the which he shall not choose but fall:

And for his death no wind of blame shall breathe,

But even his mother shall uncharge the practise

And call it accident. (4.7.61-68; emphasis added)

Mentioning Hamlet's mother here, Claudius shows that he seeks to kill Hamlet without breaking the peace with Gertrude.

To the left, Horatio sits with a quill pen and paper contemplating how to write the story of Hamlet's life and death. Beside him stand two 
ghostly figures, Rosencrantz and Guildenstern-the school chums who may also be walking the earth for a certain term for their sins. They overlook Horatio's writing project. Horatio is also featured in the painting within the painting, the last person on the far left, reaching his right hand out toward Hamlet, as if to stop him. Now the sole remainder of the court, Horatio is left to make sense of all that has happened and what it all means. Surrounding him outside the painting within the painting are several notable symbols. The tragedy and comedy masks flank the inner painting, reminding us of the theatricality of the spectacle shown. A quote from the play outlines the tomb around the top of the room's molding, "Doubt thou the stars are fire: / Doubt that the sun doth move: / Doubt truth to be a liar; / But never doubt I love" (2.2.114-17). While this sentence is taken from Hamlet's letter to Ophelia, it could also signify here Hamlet's dedication to his father and his promise to avenge him. Nonetheless, Hamlet's relationship to Ophelia is also evoked with the quote from the letter. The astronomical theme of this painting takes its inspiration from the quote as well. We see several astronomical symbols: the sky mural on the ceiling, the painting of Helios driving the chariot on the left, the sun and the planets centered above the painting within the painting, stars around the border area, and the inclusion of Tycho Brahe's portrait. The mysteries of space and the uncertainty of precisely what happens in the afterlife comingle in this painting, combining the anxieties of Hamlet's revenge quest and its inevitably suicidal result with the ambiguity of our place and purpose in the universe. This final painting is meant to signify the wrapping up of the process of apoptosis, but it also is so detailed that studying it leads to the dizzying realization that both the story of Hamlet and the process of apoptosis are more complicated and intricate than people fully realize.

Michael Benton and Sally Butcher write that paintings that portray Shakespearean subjects "are not to be viewed as mere 'stills', as it were, from an ongoing production, but as representations that have distilled influences and ideas far beyond the confines of the particular image and from outside the medium in which they are made." ${ }^{24}$ Never is this assertion truer than when considering the artwork of Julie Newdoll. Newdoll's work is truly Renaissance in nature in that it allies the sciences, art, and literature in renewed and fascinating ways. The metaphoric link between apoptosis and Hamlet's indirect suicide shows us one way in which narrative unintentionally imitates science and vice versa. If we consider the idea of apoptosis happening as a result of preserving and protecting the body, then we can also see more clearly that Hamlet restores order to the once-rotten Denmark 
through the scourging of the corrupt body politic. It is unfortunate that so many people have to die and that an outsider-Fortinbras-becomes the new head of state as a result. However, in Renaissance politics, the anxiety of just this sort of take over-hostility from within and usurpation by default-was clearly in the mind of Elizabethan political players.

MARCIA EPPICH-HARRIS, PHD, is an assistant professor of English at Marian University, in Indianapolis, Indiana, where she teaches Shakespeare and other courses in dramatic literature. Her recent publications include "Resurrect Your Darlings: Falstaff's Death(s), Resurrection(s), and Lasting Influence," in Shakespeare Newsletter (2014), and “The Liminal Space between Feminism and Misogyny: Introducing Playwright Nina Raine's Rabbit," in Studies in the Humanities (2015).

\section{NOTES}

1. While it is true that revenge heroes almost always die, a noted exception in the Renaissance is Antonio from Antonio's Revenge (1599-1602), by John Marston, which echoes some of the plot points of Hamlet. A classical example of a revenger who does not die would be Medea, who killed her children in order to wreak vengeance on her husband, Jason. Both Euripides and Seneca wrote plays about Medea.

2. Jean Baechler, Suicides, trans. Barry Cooper (New York: Basic Books, 1979), 17.

3. Girolamo Cardano, Cardanus Comfort, trans. Thomas Bedingfield, 1573. http:// books.google.com/books?pg=PT13\&dq=cardanus + comforte\&id=T2MgAQA AMAAJ. Book 3. I have modernized spelling for ease of reading.

4. Quotes from Hamlet refer to the Norton Shakespeare, 2008.

5. See Newdoll's website: www.brushwithscience.com.

6. For more on Hamlet's death as suicide see Burton R. Pollin, "Hamlet, A Successful Suicide," Shakespeare Studies 1 (1965): 240-6o. Pollin also quotes Ernest Jones's assertion that Hamlet's actions from the very beginning of the play "can lead to no other end than to his own ruin" (qtd. in Polin, 251). Other scholars acknowledge Hamlet's death is linked to his suicidal contemplation in addition to his revenge narrative: "Insofar as [Hamlet] is still suicidal, heedlessly defying augury, the impulse to self-destruction has made a home for itself within the imperative to revenge" (see William Kerrigan, Hamlet's Perfection (Baltimore: Johns Hopkins University Press, 1994), 143.

7. Bruce Alberts, et al., Essential Cell Biology (New York: Garland Science, 2010), 638.

8. Ibid.

9. Scott Freeman, Biological Science (Upper Saddle River, NJ: Prentice Hall, 2002), 404 . 
10. See Alberts, et al., 639-43.

11. Newdoll used Kronberg Castle as her setting in all of her Hamlet paintings. Newdoll traveled to Kronberg in 2009 and toured the castle in order to add realistic touches to her series. The castle is used as a touchstone for contextualization of Renaissance Danish culture, as well as historical nuance. Newdoll's paintings reflect the age of Shakespeare, not the thirteenth-century chronicle of Saxo Grammaticus from which the Hamlet narrative is derived. See Amanda Mabillard, "Shakespeare's Sources for Hamlet. Shakespeare Online." August 20, 2000. Accessed June 20, 2013. http://www.shakespeareonline.com/sources/ hamletsources.html.

12. Julie Newdoll, "Shakespeare: The Mirror up to Science" (unpublished manuscript, 2009), 6.

13. "Newdoll States," e-mail correspondence, February 5, 2012.

14. Newdoll's research into Hamlet, science, and the Elizabethan era brought her to tie-ins with astronomy, which are featured in the first and the last painting of the series. While the astronomy does not connect to apoptosis, so is beyond the scope of this study, to Newdoll it is significant because it symbolizes, "new science versus [the] old inflexible religious hold on science-a new world of scientific discovery versus old-world oppressed thinkers.... [Astronomy was] a threat to the old values, [with] unknown consequences but new possibilities" (e-mail correspondence, June 22, 2013, Newdoll, “Crants Is Crown”).

15. Newdoll, "Re: Tapestry," e-mail correspondence, December 29, 2012.

16. Newdoll, "Pathway," e-mail correspondence, February 5, 2012.

17. What we do not see plainly at the outset is that Claudius is testing Hamlet in much the same way that Hamlet tests him. Claudius needs to know if Hamlet is a threat to his power and whether or not he suspects foul play in his father's death. The Mousetrap confirms both Hamlet and Claudius's worst suspicions.

18. This is a reference to the Gospel of Matthew, in which Jesus reassures the disciples to take courage against persecution, "Are not two sparrows sold for a small coin? Yet not one of them falls to the ground without your Father's knowledge. Even all the hairs of your head are counted. So do not be afraid; you are worth more than many sparrows" (The New American Bible, 1994. St. Joseph Edition. New York: Catholic Book Publishing), Matthew 10:30-3-1.

19. Susanne L. Wofford, ed. Hamlet: Case Studies in Contemporary Criticism (Boston: Bedford/St. Martin, 1997), 107; original emphasis.

20. The checkered floor is a feature of Kronborg Castle as well.

21. Christian IV was the king of Denmark from 1588 to 1648 - contemporary with Shakespeare.

22. Roskilde Cathedral is approximately $70 \mathrm{~km}$ southwest of Kronborg Castle in Roskilde, Denmark.

23. For more on Brahe's influence on Hamlet, see Donald W. Olson, Marilynn S. Olson, and Russell L. Doescher. "The Stars of Hamlet: Shakespeare's Astronomical Inspiration?” Sky \& Telescope 96, no. 5 (November 1998): 68-73.

24. Michael Benton and Sally Butcher, "Painting Shakespeare," Journal of Aesthetic Education 32, no. 3 (1998): 65. 